\title{
Association of body mass index and hypoglycemia with mortality rates among sepsis patients: a retrospective sub- analysis of the FORECAST Study
}

Atsushi Tanikawa ( $\square$ atsushi.t0909@gmail.com )

Tohoku University Hospital

Daisuke Kudo

Tohoku University Graduate School of Medicine

Hiroyuki Ohbe

The University of Tokyo

Shigeki Kushimoto

Tohoku University Graduate School of Medicine

Research Article

Keywords: Blood glucose, body mass index, mortality, sepsis

Posted Date: June 30th, 2021

DOI: https://doi.org/10.21203/rs.3.rs-643582/v1

License: (c) (1) This work is licensed under a Creative Commons Attribution 4.0 International License. Read Full License 


\section{Abstract}

We assessed the influence of admission hypoglycemia on mortality in sepsis patients according to body mass index (BMI). We included 1,184 patients (age $\geq 16$ years) with severe sepsis diagnosed using Sepsis-2 criteria. The outcome was in-hospital mortality. Using multivariate logistic regression, we examined the association between hypoglycemia and in-hospital mortality. Overall, 1,103 patients were analyzed. Patients were divided into groups according to the initial blood glucose level, i.e., $<70$ (hypoglycemia) or $\geq 70$ (non-hypoglycemia) mg/dL, and BMl, i.e., < 18.5 (low), 18.5-24.9 (normal), or $\geq 25$ (high) kg/m². Hypoglycemia was noted in 65 patients, with low $(n=13)$, normal $(n=38)$, and high BMI $(n=14)$. Hypoglycemia patients showed higher in-hospital mortality than those without in the normal BMI group but not in the low and high BMI groups. In multivariate logistic regression, hypoglycemia was non-significantly associated with higher mortality in all patients $(p=0.268)$. However, there was a significant interaction between normal BMI patients and hypoglycemia on in-hospital mortality but not between low or high BMI patients and hypoglycemia $(p=0.0476)$. Hypoglycemia at admission in sepsis patients was associated with high mortality in normal BMI patients but not in low or high BMI patients. This association may be used as a prognostic marker in sepsis patients.

\section{Introduction}

Sepsis is a life-threatening syndrome characterized by organ dysfunction due to infection [1, 2]. It is estimated that more than 10 million sepsis patients die each year, and the number of deaths is increasing $[1,3]$.

Previous reports showed that hypoglycemia at admission is associated with high mortality in sepsis patients [4-7]. The association of body mass index (BMI) with sepsis-related mortality has also been investigated. Studies from North America and Europe demonstrated that a higher BMI was associated with lower mortality rates, while a report from China indicated that a higher BMI was not significantly associated with lower mortality rates, but a lower BMI was associated with a high risk of death [8-11].

In addition to these inconsistent results, it remains unclear whether hypoglycemia is associated with survival outcomes regardless of $\mathrm{BMI}$ or in a particular BMI category. This study aimed to assess the association between hypoglycemia at admission and mortality in sepsis patients according to BMI categories.

\section{Methods}

\section{Design, setting, and participants}

This is a retrospective secondary analysis of the Focused Outcomes Research in Emergency Care in Acute Respiratory Distress Syndrome, Sepsis, and Trauma (FORECAST) study, which described the incidence, clinical characteristics, and evolving management of sepsis in Japan. The FORECAST study was a multicenter, prospective cohort study of sepsis patients at 59 intensive care units (ICUs), and it was conducted between January 2016 and March 2017 [12]. The subjects were patients (age $\geq$ 16 years) diagnosed with severe sepsis based on the Sepsis-2 criteria in 2003 [13] because the FORECAST sepsis study was planned before the announcement of the Sepsis-3 criteria. All the patients were admitted to the ICU. Severe sepsis was defined as a diagnosis or suspicion of new-onset infection based on the history of present illness, meeting at least two criteria for systemic inflammatory response syndrome [14] and at least one criterion for organ dysfunction. Exclusion criteria included the limitation of sustained life care or post-cardiopulmonary arrest resuscitation status at the time of sepsis diagnosis.

In this secondary analysis, we screened all patients included in the FORECAST study. We excluded patients with missing data of initial blood glucose level, BMI, or survival at discharge. Because only few data were missing, we did not make any assumptions for missing data.

The FORECAST study protocol was reviewed and approved by the ethics committee of all participating institutes in the FORECAST Study Group, Japan (IRB number 014-0306, Hokkaido University the presentative for FORECAST). Data collection was performed as a part of routine clinical workup without any interventions, and data management and statistical analyses were performed anonymously. Hence, the need for informed consent was waived by the ethics committee of all participating 
institutes in the FORECAST Study Group (Appendix). All methods were performed in accordance with the relevant guidelines and regulations.

\section{Data collection}

Data were compiled by the FORECAST investigators and obtained from the FORECAST database. We collected data of patient characteristics, admission source, pre-existing comorbidities assessed using the Charlson comorbidity index, activities of daily living, suspected sites of infection, organ dysfunction, sepsis-related severity scores, duration of mechanical ventilation and ICU stays, and survival information 28 days after ICU admission and at hospital discharge. The Sequential Organ Failure Assessment (SOFA) [15] and the Acute Physiology and Chronic Health Evaluation II (APACHE II) scores [16] were calculated using physiological and laboratory data obtained at the initial examination as a part of the routine medical workup. Blood glucose levels were measured using a blood gas analyzer, as recommended by the international sepsis guidelines [17], and not using a glucometer. All glucose levels were measured before corticosteroid administration, if possible.

\section{Date definitions}

Patients were divided into two groups depending on their initial blood glucose levels: $<70 \mathrm{mg} / \mathrm{dL}$ (hypoglycemia) or $\geq 70 \mathrm{mg} / \mathrm{dL}$ (non-hypoglycemia). Although not universally defined, blood glucose levels of $<70 \mathrm{mg} / \mathrm{dL}$ are widely accepted as the definition of hypoglycemia [18].

BMI classification was made based on the definition of the Japan Society for the Study of Obesity [19]: $<18.5 \mathrm{~kg} / \mathrm{m}^{2}$ (low BMI), $18.5-24.9 \mathrm{~kg} / \mathrm{m}^{2}$ (normal BMI), and $\geq 25 \mathrm{~kg} / \mathrm{m}^{2}$ (high BMI). Septic shock and organ dysfunction were defined using the Sepsis-2 criteria [13]. The Charlson comorbidity index was classified into four groups as previously defined: 0 (none), 1-2 (low), 3-4 (moderate), and $\geq 5$ (high) points [20].

\section{Outcome}

The primary outcome measure was in-hospital mortality.

\section{Statistical analysis}

Descriptive statistics included counts (proportions) for categorical variables and medians (interquartile range, IQR) for continuous variables, as not all variables had normal distribution. Categorical variables were compared using chi-square tests, and continuous variables were compared using the Mann-Whitney $U$ test. We performed a multivariable logistic regression analysis using in-hospital mortality as the objective variable and blood glucose level of $<70 \mathrm{mg} / \mathrm{dL}$ or not, three BMl category groups, age, SOFA score, and Charlson comorbidity index, as explanatory variables. To examine the heterogeneity of the impact of hypoglycemia on in-hospital mortality across each BMI category, we performed a multivariable logistic regression analysis including the interaction term between BMI category and hypoglycemia in each BMI category. Statistical significance was defined as $p<0.05$, and statistical analyses were performed using JMP® 15 (SAS Institute Inc., Cary, NC, USA).

\section{Results}

The FORECAST study registered 1,184 patients. Eighty-one patients were excluded because of missing data regarding the initial blood glucose level, BMI, or survival at hospital discharge. Finally, we analyzed data from 1,103 patients with severe sepsis. The patients were divided into two groups according to blood glucose levels: 65 patients with hypoglycemia and 1,038 patients without hypoglycemia. Furthermore, patients with hypoglycemia were divided according to BMI categories: $13 / 1,103$ (1\% of all included patients) with a low BMI, 38/1,103 (2\%) with a normal BMI, and 14/1,103 (1\%) with a high BMI. Patients without hypoglycemia were also divided similarly: 210/1,103 (19\%), 584/1,103 (53\%), and 244/1,103 (22\%), respectively (Fig. 1).

\section{Patient characteristics and clinical outcomes}

Patient characteristics are shown in Table 1 (detailed characteristics are shown in Supplemental Digital Content 1). Median patient age was 73 (64-81) years, and median BMI was $21.7 \mathrm{~kg} / \mathrm{m}^{2}(19.0-24.7)$. Of the 1,038 patients, $23.3 \%$ were diagnosed with diabetes mellitus before admission. The proportion of patients with pre-existing diabetes was similar between patients with 
and without hypoglycemia in all BMI categories. The most suspected site of infection was the lung (31.1\%), followed by the abdomen (25.7\%). SOFA score, APACHE II score, and lactate levels tended to be higher in patients with hypoglycemia than in those without hypoglycemia in all BMI categories.

Table 1

Characteristics of patients classified by body mass index category and glucose levels on admission

\begin{tabular}{|c|c|c|c|c|c|c|c|c|c|c|}
\hline & \multirow{3}{*}{$\begin{array}{l}\begin{array}{l}\text { All } \\
\text { patients }\end{array} \\
(n= \\
1,103)\end{array}$} & \multicolumn{3}{|c|}{ BMI low $(n=223)$} & \multicolumn{3}{|c|}{$\begin{array}{l}\text { BMI normal }(n= \\
622)\end{array}$} & \multicolumn{3}{|c|}{ BMI high $(n=258)$} \\
\hline & & Glucose & Glucose & $p$ value & Glucose & Glucose & $p$ value & Glucose & Glucose & $p$ value \\
\hline & & $\begin{array}{l}<70 \\
\mathrm{mg} / \mathrm{dL}\end{array}$ & $\begin{array}{l}\geq 70 \\
\mathrm{mg} / \mathrm{dL}\end{array}$ & & $\begin{array}{l}<70 \\
\mathrm{mg} / \mathrm{dL}\end{array}$ & $\begin{array}{l}\geq 70 \\
\mathrm{mg} / \mathrm{dL}\end{array}$ & & $\begin{array}{l}<70 \\
\mathrm{mg} / \mathrm{dL}\end{array}$ & $\begin{array}{l}\geq 70 \\
\mathrm{mg} / \mathrm{dL}\end{array}$ & \\
\hline & & $(n=13)$ & $\begin{array}{l}(n= \\
210)\end{array}$ & & $(n=38)$ & $\begin{array}{l}(n= \\
584)\end{array}$ & & $(n=14)$ & $\begin{array}{l}(n= \\
244)\end{array}$ & \\
\hline Age (years) & $\begin{array}{l}73(64- \\
81)\end{array}$ & $\begin{array}{l}71 \\
(58.0- \\
79.5)\end{array}$ & $\begin{array}{l}75(67- \\
83)\end{array}$ & 0.224 & $\begin{array}{l}74 \\
(69.5- \\
80)\end{array}$ & $\begin{array}{l}73(64- \\
82)\end{array}$ & 0.297 & $\begin{array}{l}68(64- \\
72.5)\end{array}$ & $\begin{array}{l}69(61- \\
80)\end{array}$ & 0.581 \\
\hline Sex, male & $\begin{array}{l}664 \\
(60.2)\end{array}$ & $6(46.2)$ & $\begin{array}{l}114 \\
(54.3)\end{array}$ & 0.568 & $\begin{array}{l}19 \\
(50.0)\end{array}$ & $\begin{array}{l}368 \\
(63.0)\end{array}$ & 0.109 & $6(42.8)$ & $\begin{array}{l}151 \\
(61.9)\end{array}$ & 0.156 \\
\hline $\begin{array}{l}\text { BMI } \\
\left(\mathrm{kg} / \mathrm{m}^{2}\right)\end{array}$ & $\begin{array}{l}21.7 \\
(19.0- \\
24.7)\end{array}$ & $\begin{array}{l}15.6 \\
(14.9- \\
17.4)\end{array}$ & $\begin{array}{l}16.8 \\
(15.2- \\
17.8)\end{array}$ & 0.429 & $\begin{array}{l}21.2 \\
(19.7- \\
23.2)\end{array}$ & $\begin{array}{l}21.5 \\
(19.9- \\
23.1)\end{array}$ & 0.722 & $\begin{array}{l}29.8 \\
(26.4- \\
31.8)\end{array}$ & $\begin{array}{l}27.0 \\
(25.8- \\
30.4)\end{array}$ & 0.123 \\
\hline $\begin{array}{l}\text { Glucose } \\
\text { (mg/dL) }\end{array}$ & $\begin{array}{l}136 \\
(104- \\
188)\end{array}$ & $\begin{array}{l}40 \\
(25.5- \\
61)\end{array}$ & $\begin{array}{l}133.5 \\
(105- \\
179)\end{array}$ & $<.0001$ & $\begin{array}{l}51.5 \\
(36- \\
63)\end{array}$ & $\begin{array}{l}139 \\
(110- \\
192)\end{array}$ & $<.0001$ & $\begin{array}{l}59(47- \\
53)\end{array}$ & $\begin{array}{l}146.5 \\
(116.5- \\
199)\end{array}$ & $\dot{0} .0001$ \\
\hline SOFA score & $\begin{array}{l}9(6- \\
11)\end{array}$ & $\begin{array}{l}10(7- \\
14)\end{array}$ & $\begin{array}{l}9(6- \\
11)\end{array}$ & 0.177 & $\begin{array}{l}11(9- \\
14.5)\end{array}$ & $\begin{array}{l}8(6- \\
11)\end{array}$ & $<.0001$ & $\begin{array}{l}12(10- \\
13)\end{array}$ & $\begin{array}{l}8(5- \\
12)\end{array}$ & 0.00168 \\
\hline $\begin{array}{l}\text { APACHE II } \\
\text { score }\end{array}$ & $\begin{array}{l}22(17- \\
29)\end{array}$ & $\begin{array}{l}26(20- \\
31)\end{array}$ & $\begin{array}{l}22(17- \\
30)\end{array}$ & 0.433 & $\begin{array}{l}29(21- \\
38.5)\end{array}$ & $\begin{array}{l}22(17- \\
29)\end{array}$ & 0.0003 & $\begin{array}{l}29.5 \\
(23- \\
35.5)\end{array}$ & $\begin{array}{l}22(16- \\
30)\end{array}$ & 0.087 \\
\hline $\begin{array}{l}\text { Pre-existing } \\
\text { diabetes } \\
\text { mellitus }\end{array}$ & $\begin{array}{l}257 \\
(23.3)\end{array}$ & $2(15.4)$ & $\begin{array}{l}34 \\
(15.7)\end{array}$ & 0.975 & 7 (18.4) & $\begin{array}{l}129 \\
(22.1)\end{array}$ & 0.596 & $4(28.6)$ & $\begin{array}{l}82 \\
(33.6)\end{array}$ & 0.698 \\
\hline $\begin{array}{l}\text { Charlson } \\
\text { Comorbidity } \\
\text { Index }\end{array}$ & $1(0-2)$ & $1(0-2)$ & $1(0-2)$ & 0.710 & $1(0-2)$ & $1(0-2)$ & 0.629 & $\begin{array}{l}1(0- \\
3.5)\end{array}$ & $1(0-2)$ & 0.947 \\
\hline $\begin{array}{l}\text { Septic } \\
\text { shock }\end{array}$ & $\begin{array}{l}684 \\
(62.0)\end{array}$ & $\begin{array}{l}11 \\
(84.6)\end{array}$ & $\begin{array}{l}137 \\
(65.2)\end{array}$ & 0.151 & $\begin{array}{l}31 \\
(81.6)\end{array}$ & $\begin{array}{l}359 \\
(61.5)\end{array}$ & 0.0130 & $\begin{array}{l}12 \\
(85.7)\end{array}$ & $\begin{array}{l}134 \\
(54.9)\end{array}$ & 0.0238 \\
\hline Number of & s wi & $\sin \theta$ & SOFA & 58. & $\mathrm{NF} \|$ & 112 & & & & \\
\hline
\end{tabular}

The clinical outcomes are shown in Table 2 (detailed results of outcome measures are shown in Supplemental Digital Content 2). In all patients, the in-hospital and 28-day mortality rates were 253/1103 (22.9\%) and 200/1093 (18.3\%), respectively. The inhospital and 28-day mortality rates were higher in patients with hypoglycemia than in those without hypoglycemia in the normal BMI group (18/38 [47.4\%] vs. 119/584 [20.4\%], $p=0.0001$, and 16/38 [42.1\%] vs. 89/577 [15.4\%], $p<0.0001$, respectively). However, these rates were similar in the low and high BMI groups. 
Table 2

Clinical outcomes in patients with or without hypoglycemia classified by body mass index

\begin{tabular}{|c|c|c|c|c|c|c|c|c|c|c|}
\hline & \multirow{3}{*}{$\begin{array}{l}\begin{array}{l}\text { All } \\
\text { patients }\end{array} \\
(n= \\
1,103)\end{array}$} & \multicolumn{3}{|c|}{ BMI low $(n=223)$} & \multicolumn{3}{|c|}{$\begin{array}{l}\text { BMI normal }(n= \\
622)\end{array}$} & \multicolumn{3}{|c|}{ BMI high $(n=258)$} \\
\hline & & Glucose & Glucose & $p$ & Glucose & Glucose & $p$ value & Glucose & Glucose & $p$ \\
\hline & & $\begin{array}{l}<70 \\
\mathrm{mg} / \mathrm{dL}\end{array}$ & $\begin{array}{l}\geq 70 \\
\mathrm{mg} / \mathrm{dL}\end{array}$ & & $\begin{array}{l}<70 \\
\mathrm{mg} / \mathrm{dL}\end{array}$ & $\begin{array}{l}\geq 70 \\
\mathrm{mg} / \mathrm{dL}\end{array}$ & & $\begin{array}{l}<70 \\
\mathrm{mg} / \mathrm{dL}\end{array}$ & $\begin{array}{l}\geq 70 \\
\mathrm{mg} / \mathrm{dL}\end{array}$ & \\
\hline & & $(n=13)$ & $\begin{array}{l}(n= \\
210)\end{array}$ & & $(n=38)$ & $(n=584)$ & & $(n=14)$ & $\begin{array}{l}(n= \\
244)\end{array}$ & \\
\hline $\begin{array}{l}\text { In-hospital } \\
\text { mortality }\end{array}$ & $\begin{array}{l}253 / 1103 \\
(22.9)\end{array}$ & $\begin{array}{l}3 / 13 \\
(23.1)\end{array}$ & $\begin{array}{l}53 / 210 \\
(25.2)\end{array}$ & 0.862 & $\begin{array}{l}18 / 38 \\
(47.4)\end{array}$ & $\begin{array}{l}119 / 584 \\
(20.4)\end{array}$ & 0.0001 & $\begin{array}{l}3 / 14 \\
(21.4)\end{array}$ & $\begin{array}{l}57 / 244 \\
(23.4)\end{array}$ & 0.868 \\
\hline $\begin{array}{l}\text { 28-day } \\
\text { mortality }\end{array}$ & $\begin{array}{l}200 / 1093 \\
(18.3)\end{array}$ & $\begin{array}{l}3 / 13 \\
(23.1)\end{array}$ & $\begin{array}{l}43 / 209 \\
(20.6)\end{array}$ & 0.829 & $\begin{array}{l}16 / 38 \\
(42.1)\end{array}$ & $\begin{array}{l}89 / 577 \\
(15.4)\end{array}$ & $<.0001$ & $\begin{array}{l}3 / 14 \\
(21.4)\end{array}$ & $\begin{array}{l}46 / 242 \\
(19.0)\end{array}$ & 0.823 \\
\hline $\begin{array}{l}\text { ICU-free } \\
\text { days }\end{array}$ & $\begin{array}{l}19(11- \\
24)\end{array}$ & $\begin{array}{l}16.5 \\
(10-24)\end{array}$ & $\begin{array}{l}20(13- \\
25)\end{array}$ & 0.355 & $\begin{array}{l}17 \\
(9.5- \\
22)\end{array}$ & $\begin{array}{l}19(10- \\
24)\end{array}$ & 0.437 & $\begin{array}{l}13(4- \\
20)\end{array}$ & $\begin{array}{l}20(11- \\
24)\end{array}$ & 0.097 \\
\hline $\begin{array}{l}\text { Length of } \\
\text { hospital } \\
\text { stay }\end{array}$ & $\begin{array}{l}24(12- \\
46)\end{array}$ & $\begin{array}{l}22 \\
(5.5- \\
40)\end{array}$ & $\begin{array}{l}24(14- \\
45)\end{array}$ & 0.524 & $\begin{array}{l}27(4- \\
44)\end{array}$ & $\begin{array}{l}25.5 \\
(13-47)\end{array}$ & 0.260 & $\begin{array}{l}23.5 \\
(19- \\
52.5)\end{array}$ & $\begin{array}{l}21(11- \\
46)\end{array}$ & 0.200 \\
\hline \multicolumn{11}{|c|}{ Number of patients with missing data: 28-day mortality, 10; ICU-free days, 210} \\
\hline \multicolumn{11}{|c|}{ BMI, body mass index; ICU, intensive care unit } \\
\hline
\end{tabular}

\section{Interaction between hypoglycemia and BMI category for in-hospital mortality}

In the multivariate logistic regression model, hypoglycemia was not significantly associated with higher mortality in all patients (Table 3). However, there was a significant interaction between patients with normal BMI and hypoglycemia on in-hospital mortality (OR 2.32, 95\% $\mathrm{Cl} 1.05-5.07, p$ value for interaction $=0.0476)$, whereas there was no interaction between patients with low or high BMI and hypoglycemia (Fig. 2).

Table 3

Odds ratios for in-hospital mortality

\begin{tabular}{|llll|}
\hline Variables & Odds ratio & $\mathbf{9 5 \%}$ Cl & $p$ value \\
\hline Glucose level $<70 \mathrm{mg} / \mathrm{dL}$ & 1.41 & $0.77-2.58$ & 0.268 \\
\hline BMI low vs. normal & 1.19 & $0.78-1.81$ & 0.407 \\
\hline BMI high vs. normal & 1.09 & $0.73-1.62$ & 0.662 \\
\hline BMI high vs. low & 0.92 & $0.56-1.50$ & 0.724 \\
\hline Age & 1.02 & $1.00-1.03$ & 0.0189 \\
\hline SOFA & 1.18 & $1.13-1.23$ & $<0.0001$ \\
\hline Charlson Comorbidity Index & 1.22 & $1.12-1.34$ & $<0.0001$ \\
\hline BMI, body mass index; Cl, confidence interval; SOFA, Sequential Organ Failure Assessment \\
\hline
\end{tabular}

\section{Discussion}

We found that hypoglycemia at admission in sepsis patients was associated with high mortality in patients with normal BMI but not in those with low and high BMI. To the best of our knowledge, this is the first study to examine the association between hypoglycemia at admission and mortality in sepsis patients according to BMI categories. 
Hypoglycemia is associated with a high mortality rate in sepsis patients and critically ill patients [5-7]. The NICE-SUGAR study demonstrated that hypoglycemia was associated with an increased risk of death, especially among patients with distributive shock [6]. Patients with both septic shock and hypoglycemia on the day of enrolment had a 2.5-fold higher mortality rate than those without septic shock and hypoglycemia in a multicenter observational study of sepsis patients in Japan [5].

The distribution of BMI in the population varies widely across countries and regions. A population-based study of adults was conducted in 200 countries, and it revealed that the proportions of high $\mathrm{BMI}(\mathrm{BMI} \geq 25)$, normal $\mathrm{BMI}$, and low $\mathrm{BMI}(\mathrm{BMI}<18.5)$ were $50-60 \%, 30 \%$, and $<5 \%$, respectively, in Western countries, and $30 \%, 50 \%$, and $10-20 \%$, respectively, in East Asian countries [20]. Observational studies in sepsis patients of Western countries showed that the population with high BMl accounted for more than $50 \%$ and that of low BMI accounted for less than $10 \%$, and sepsis patients with high BMI had better survival outcomes, suggesting an "obesity paradox" [8-10]. By contrast, a study conducted in China reported that low BMI was an independent factor associated with reduced 90-day survival [11]. In addition, a retrospective observational study using two cohorts in Japan (including cohort of the FORECAST study) showed that patients with low BMI had a significantly higher 28-day mortality than those without low BMI [21]. However, previous studies did not address the association between hypoglycemia and mortality in sepsis patients according to BMI categories.

The mechanism by which a low BMI and high BMI were not associated with worse mortality in patients with hypoglycemia was not clear. Adipose tissue and lipoproteins are related to BMI [22] as well as inflammation [23, 24]. The amount of adipose tissue and lipoproteins may depend on host defense in patients with sepsis and hypoglycemia. Further studies should be conducted to elucidate the mechanisms underlying the biological reactions of adipose tissue and lipoproteins to hypoglycemia in sepsis patients.

This study has some limitations. First, because these data were collected before the sepsis-3 criteria were published, the definition of sepsis used in this study was different from the latest definition. Second, the number of patients with hypoglycemia was too small to be assessed with sufficient statistical power. Third, all of our participants were Japanese; thus, generalizability might be limited to East Asians. Fourth, we could use few explanatory variables in the multivariate analysis because not many patients died.

In conclusion, hypoglycemia at admission in sepsis patients was associated with high mortality in patients with normal BMI, but not in those with low and high BMI. This association may be used as a prognostic marker in sepsis patients. In the future, larger cohort studies are needed to confirm this finding.

\section{Declarations}

\section{Acknowledgements}

We thank the core investigators of the FORECAST sepsis study (Appendix) for providing the dataset. We are grateful to all investigators involved in the FORECAST sepsis study for contributing to data collection and assessment.

\section{Authors' contributions}

All authors contributed to the study conception and design. Material preparation, data collection, and analysis were performed by AT and DK. Statistical analysis was reviewed by DK and HO. The first draft of the manuscript was written by AT. The manuscript was reviewed and edited by DK and SK, and all authors commented on the previous versions of the manuscript. All authors read and approved the final manuscript.

\section{Conflict of Interest and Source of Funding}

This work was supported by grants from JSPS KAKENHI [grant number JP 19H03755] for language editing. The authors declare that they have no competing interests.

\section{Availability of data and materials}


The dataset of the FORECAST sepsis study is not publicly available, based on the decision by the Japanese Association for Acute Medicine.

\section{Ethics approval and consent to participate}

The study protocol was reviewed and approved by the ethics committee of all participant institutes in the Japanese Association for Acute Medicine (JAAM) study group, Japan. (IRB number 014-0306 on Hokkaido University, the representative for FORECAST).

\section{References}

1. Singer, M. et al. The third international consensus definitions for sepsis and septic shock (sepsis-3). JAMA, 315, 801-810 (2016).

2. Rudd, K. E. et al. Global, regional, and national sepsis incidence and mortality, 1990-2017: analysis for the Global Burden of Disease Study. Lancet, 395, 200-211 (2020).

3. Gaieski, D. F., Edwards, J. M., Kallan, M. J. \& Carr, B. G. Benchmarking the incidence and mortality of severe sepsis in the United States. Crit. Care Med, 41, 1167-1174 (2013).

4. Plummer, M. P. et al. Dysglycaemia in the critically ill and the interaction of chronic and acute glycaemia with mortality. Intensive Care Med, 40, 973-980 (2014).

5. Kushimoto, S. et al. Impact of blood glucose abnormalities on outcomes and disease severity in patients with severe sepsis: an analysis from a multicenter, prospective survey of severe sepsis. PLOS ONE, 15, e0229919 (2020).

6. NICE-SUGAR Study Investigators. Hypoglycemia and risk of death in critically ill patients. N. Engl. J. Med, 367, 1108-1118 (2012).

7. Hermanides, J. et al. Hypoglycemia is associated with intensive care unit mortality. Crit. Care Med, 38, 1430-1434 (2010).

8. Prescott, H. C., Chang, V. W., O’Brien, J. M. Jr, Langa, K. M. \& Iwashyna, T. J. Obesity and 1-year outcomes in older Americans with severe sepsis. Crit. Care Med, 42, 1766-1774 (2014).

9. Sakr, Y. et al. Obesity is associated with increased morbidity but not mortality in critically ill patients. Intensive Care Med, 34, 1999-2009 (2008).

10. Pepper, D. J. et al. Does obesity protect against death in sepsis? A retrospective cohort study of 55,038 adult patients. Crit. Care Med, 47, 643-650 (2019).

11. Zhou, Q. et al. Impact of body mass index on survival of medical patients with sepsis: a prospective cohort study in a university hospital in China. BMJ. Open, 8, e021979 (2018).

12. Abe, T. et al. Characteristics, management, and in-hospital mortality among patients with severe sepsis in intensive care units in Japan: the FORECAST study. Crit. Care, 22, 322 (2018).

13. Levy, M. M. et al. 2001 SCCM/ESICM/ACCP/ATS/SIS international sepsis definitions conference. Crit. Care. Med. 31, 12501256(2003).

14. Bone, R. C. et al. Definitions for sepsis and organ failure and guidelines for the use of innovative therapies in sepsis. The ACCP/SCCM Consensus Conference Committee. American College of Chest Physicians/Society of Critical Care Medicine. Chest. 101, 1644-1655(1992).

15. Vincent, J. L. et al. Use of the SOFA score to assess the incidence of organ dysfunction/failure in intensive care units: results of a multicenter, prospective study. Working group on "sepsis-related problems" of the European Society of Intensive Care Medicine. Crit. Care. Med, 26, 1793-1800 (1998).

16. Knaus, W. A., Draper, E. A., Wagner, D. P. \& Zimmerman, J. E. Apache II: a severity of disease classification system. Crit. Care. Med, 13, 818-829 (1985).

17. Dellinger, R. P. et al. Surviving sepsis campaign: international guidelines for management of severe sepsis and septic shock: 2012. Crit. Care Med, 41, 580-637 (2013). 
18. Seaquist, E. R. et al. Hypoglycemia and diabetes: a report of a workgroup of the American Diabetes Association and the Endocrine Society. J. Clin. Endocrinol. Metab, 98, 1845-1859 (2013).

19. Examination Committee of Criteria for 'Obesity Disease' in Japan; Japan Society for the Study of Obesity. New criteria for "obesity disease" in. Jpn. Circ. J, 66, 987-992 (2002).

20. Yang, Y., Yang, K. S., Hsann, Y. M., Lim, V. \& Ong, B. C. The effect of comorbidity and age on hospital mortality and length of stay in patients with sepsis. J. Crit. Care, 25, 398-405 (2010).

21. Oami, T. et al. Association between low body mass index and increased 28-day mortality of severe sepsis in Japanese cohorts. Sci. Rep, 11, 1615 (2021).

22. Bastien, M., Poirier, P., Lemieux, I. \& Després, J. P. Overview of epidemiology and contribution of obesity to cardiovascular disease. Prog. Cardiovasc. Dis, 56, 369-381 (2014).

23. McGown, C., Birerdinc, A. \& Younossi, Z. M. Adipose tissue as an endocrine organ. Clin. Liver. Dis, 18, 41-58 (2014).

24. Murch, O., Collin, M., Hinds, C. J. \& Thiemermann, C. Lipoproteins in inflammation and sepsis. I. Basic science. Intensive Care Med, 33, 13-24 (2007).

\section{Figures}

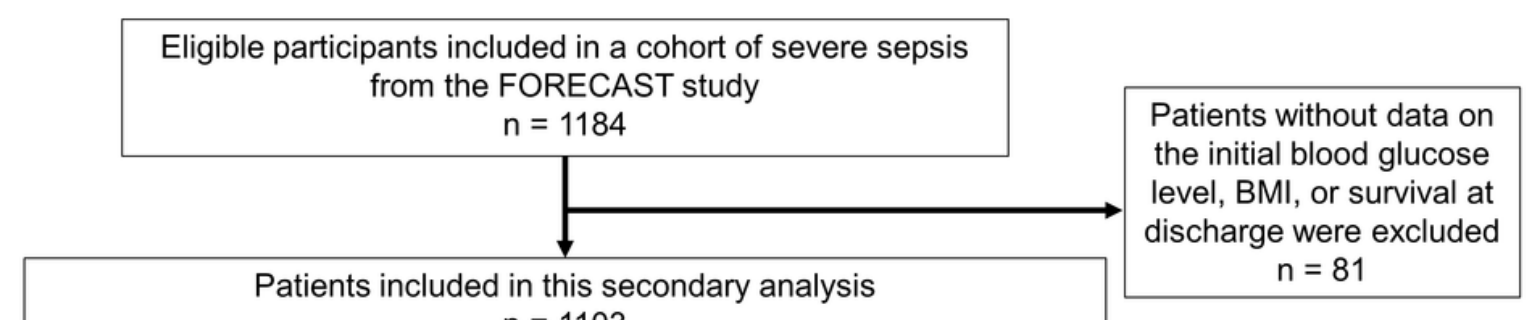

Categorized based on the initial blood glucose value

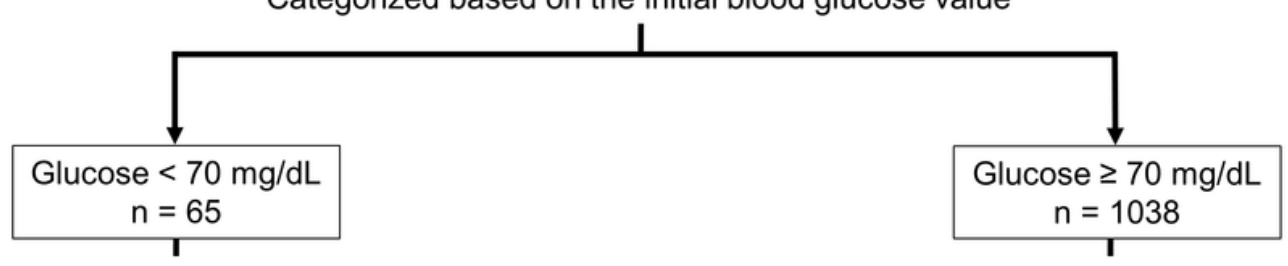

Categorized based on BMI (as per the classification of the Japan Society for the Study of Obesity)

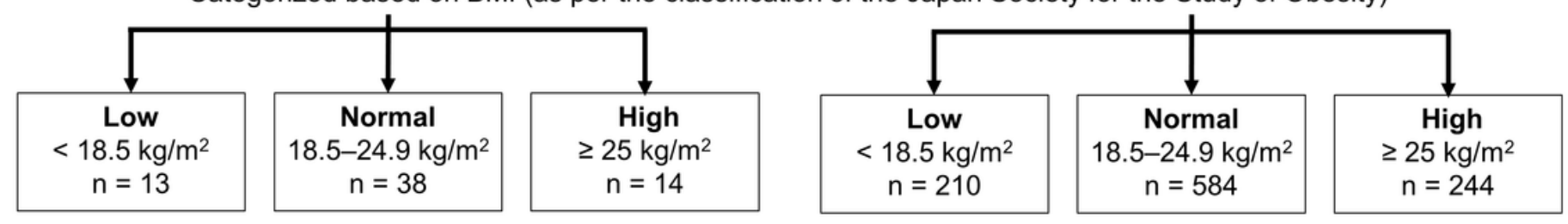

Figure 1

Flowchart of the patient selection process 


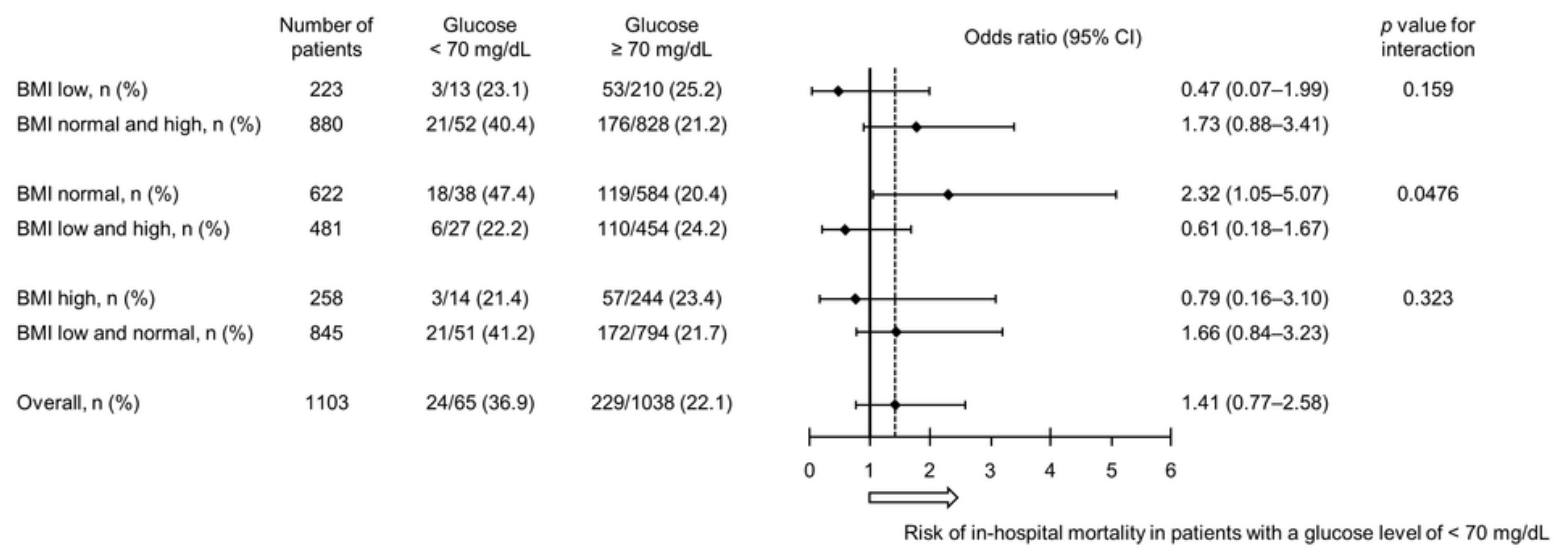

Figure 2

Interaction between body mass index category and hypoglycemia for in-hospital morality Odds ratios of hypoglycemia for inhospital mortality in each BMl category are shown. Odds ratios and $95 \% \mathrm{Cls}$ were obtained using a multivariable logistic regression model. Squares indicate odds ratios. Horizontal bars indicate $95 \%$ confidence intervals. The dotted vertical line indicates the odds ratio of hypoglycemia for in-hospital mortality in all patients. Low BMI, $<18.5 \mathrm{~kg} / \mathrm{m} 2$; normal BMl, 18.5-24.9 $\mathrm{kg} / \mathrm{m} 2$; high $\mathrm{BMI}, \geq 25 \mathrm{~kg} / \mathrm{m} 2$. BMl, body mass index; $\mathrm{Cl}$, confidence interval

\section{Supplementary Files}

This is a list of supplementary files associated with this preprint. Click to download.

- Forecastsupplementaltable2AT0621.docx

- Forecastsupplementaltable1AT0621.docx

- Appendix0506.docx 